STUDI

FRANCESI

\section{Studi Francesi}

Rivista quadrimestrale fondata da Franco Simone

194 (LXV | II) | 2021

Baudelaire et son cénacle

\title{
FLORENCE BOUCHET, Souvenir traumatique et mémoire salutaire. La bataille d'Azincourt chez les auteurs français du $\mathrm{Xv}^{\mathrm{e}}$ siècle
}

\section{Paola Cifarelli}

\section{(2) OpenEdition}

\section{Journals}

Édition électronique

URL : https://journals.openedition.org/studifrancesi/44804

DOI : $10.4000 /$ studifrancesi.44804

ISSN : 2427-5856

Éditeur

Rosenberg \& Sellier

\section{Édition imprimée}

Date de publication : 1 août 2021

Pagination : 355

ISSN : 0039-2944

\section{Référence électronique}

Paola Cifarelli, « FLORENCE BOUCHET, Souvenir traumatique et mémoire salutaire. La bataille d'Azincourt chez les auteurs français du xve siècle », Studi Francesi [En ligne], 194 (LXV | II) | 2021, mis en ligne le 06 septembre 2021, consulté le 15 octobre 2022. URL : http://journals.openedition.org/studifrancesi/ 44804 ; DOI : https://doi.org/10.4000/studifrancesi.44804

Ce document a été généré automatiquement le 15 octobre 2022.

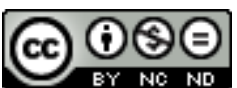

Creative Commons - Attribution - Pas d'Utilisation Commerciale - Pas de Modification 4.0 International - CC BY-NC-ND 4.0

https://creativecommons.org/licenses/by-nc-nd/4.0/ 


\title{
FLORENCE BOUCHET, Souvenir
} traumatique et mémoire salutaire. La bataille d'Azincourt chez les auteurs français $d u \mathrm{XV}^{\mathrm{e}}$ siècle

\author{
Paola Cifarelli
}




\section{RÉFÉRENCE}

FLORENCE BOUCHET, Souvenir traumatique et mémoire salutaire. La bataille d'Azincourt chez les auteurs français $d u \mathrm{XV}^{\mathrm{e}}$ siècle, "Cahiers de recherches médiévales et humanistes" 39, 2020, fasc. 1, pp. 391-416.

1 Un corpus de textes variés comprenant chroniques, traités, romans, poèmes, journaux et débats permet à l'A. d'étudier les témoignages des évocations de la célèbre défaite d'Azincourt (1415), dont la fonction à la fois mémorielle et exemplaire, entre idéalisme chevaleresque et pessimisme moral, est à la base de tous les textes pris en considération. Trois éléments sont successivement soumis à l'analyse; en premier lieu, les descriptions de la bataille se révèlent parfois divergentes dans les détails concernant la supériorité numérique des Français, l'influence du terrain de combat et l'évaluation des tactiques choisies par les deux ennemis. Ensuite, certains épisodes ou personnages acquièrent un statut exemplaire et mettent l'accent sur des thèmes moralisants comme l'orgueil abattu, le caractère providentiel de la guerre ou l'opposition entre générations ou classes sociales; enfin, le deuil des femmes et plus généralement la charge pathétique de cet événement tragique prennent un relief particulier dans les œuvres poétiques. L'aspiration à la paix est un autre élément commun qui relie plusieurs de ces témoignages, par-delà les différences dans la modulation des émotions exprimées dans les différents textes. 